\title{
Çok Yönlü Liderlik Yönelimleri Ölçeği (ÇYLYÖ): Geçerlik ve Güvenirlik Çalışması
}

\author{
Multidimensional Leadership Orientations Scale (MLOS): Validity and Reliability Study
}

\section{Mücahit DURSUN}

Arş. Gör., Gazi Üniversitesi, Spor Bilimleri Fakültesi, mucahitdursun1903@gmail.com

https://orcid.org/0000-0002-7786-0741

\author{
Mehmet GÜNAY \\ Prof. Dr., Gazi Üniversitesi, Spor Bilimleri Fakültesi, \\ mgunay@gazi.edu.tr \\ https://orcid.org/0000-0003-0047-2203

\section{İbrahim Fatih YENEL} \\ Dr. Öğr. Üyesi, Gazi Üniversitesi, Spor Bilimleri Fakültesi, \\ fyenel@gazi.edu.tr \\ https://orcid.org/0000-0001-9480-2087
}

\section{ÖZET}

Anahtar

Kelimeler:

Liderlik,

Liderlik

Yönelimleri,

Geçerlik,

Güvenilirlik

Keywords:

Leadership,

Leadership

Orientations,

Validity,

Reliability,
Bu çalışmada, bireylerin liderlik yönelimlerini belirlemeye yönelik geçerli ve güvenilir bir ölçme aracının geliştirilmesi amaçlanmuştır. Çalı̧̧ma, 2018-2019 eğitim- öğretim yılı bahar döneminde Gazi Üniversitesi ve Hacı Bayram Veli Üniversitelerinin farkl fakültelerinde ögrenim gören 266'sı kadın ve 237'si erkek olmak üzere toplam 503 üniversite ögrencisi üzerinde yürütülmüştür. Ölçme aracının yapı geçerliliğini test etmek için ilk olarak Açımlayıcı Faktör Analizi (AFA) yapılmıştır. AFA sonucunda toplam varyansın \%52,807'sini açılkayan, 19 madde ve dört alt boyuttan oluşan bir yapı elde edilmiştir. Ortaya çıkan bu yapının doğrulaması amacıyla yapılan Doğrulayıcı Faktör Analizi (DFA) sonucunda, yeterli uyum indekslerine ulașılmıștır. Maddelerin ayırt ediciliğini tespit etmek için düzeltilmiş madde test korelasyonu incelenmiş ve $\% 27$ 'lik alt-üst yöntemi ile madde puan ortalamaları arasında fark olup olmadiğı karşılaştırılmıştır. Ölçme aracının güvenilirliği Cronbach Alfa iç tutarlılık katsayısı ile incelenmiş ve çıkan güvenilirlik katsayılarının ölçeğin oldukça güvenilir olduğuna dair kanıt sağlamıştır. Bu bulgular doğrultusunda, Çok Yönlü Liderlik Yönelimleri Ölçeği (ÇYLYÖ)'nin geçerli ve güvenilir ölçümler yapabilen bir veri toplama aracı olduğu söylenebilir.

\section{ABSTRACT}

In this study, it was aimed to develop a valid and reliable measurement tool for determining the leadership orientations of individuals. The study was conducted on a total of 503 university students, 266 females and 237 males, who studied at different faculties of Gazi and Hacl Bayram Veli Universities during the spring semester of the 2018-2019 academic year. In order to test the structural validity of the measuring instrument, first, Exploratory Factor Analysis (EFA) was conducted. As a result of EFA, a structure consisting of 19 items and four sub-dimensions was obtained, explaining 52,807\% of the total variance. As a result of the confirmatory Factor Analysis (DFA) conducted to confirm this structure, sufficient compliance indexes were reached. To determine the differentiability of items, the corrected item test correlation was examined and it was compared whether there was a difference between the top-down method of $27 \%$ and the item score means. The reliability of the measuring instrument was examined with the Cronbach Alpha internal coherence coefficient, providing evidence that the resulting reliability coefficients were highly reliable on the scale. In line with these findings, it is tellable that Multidimensional Leadership Orientations Scale (MLOS) is a data collection tool capable of performing valid and reliable measurements. 


\section{GIRISS}

Toplumun öznesi olan insan doğar doğmaz bir grubun doğal üyesi olur ve sosyal bir varlık olarak hayatını sürdürür. Bu süreç içerisinde bazı ihtiyaçlarını kendisi giderebilirken bazı ihtiyaçlarını da bir gruba dahil olarak gerçekleştirebilir. Bu grup içerisinde tek başına gerçekleştiremediğimiz amaç ve hedefler için bize yol gösterecek, kılavuzluk edecek, iş birliği yapmak için itici güç olacak kişiye yani lidere ihtiyaç duyarız.

Literatürde yer alan çalışmalar incelendiğinde, liderlik ile ilgili muhtelif tanımların yapıldığı görülmektedir. Erol (2008:525) liderliği, "bir grup insanı belirli amaçlar etrafinda toplayabilme ve bu amaçları gerçekleştirmek için onlar harekete geçirme bilgi ve yeteneklerinin toplamıdır", şeklinde tanımlamıştır. Başka bir tanımda ise Başaran (2004:67), "liderlik (önderlik) tanımında ortak amaçlar için birleşen insanları, amaçları gerçekleştirmeye etkileme süreci" olarak ifade etmiştir. Aydın (2013:81), "liderlik, bir topluluk performansıdır" şeklinde, Kalfa (2019:74) ise liderliği belirli bir grubun özellikle duygularını etkileyerek onlara belirli işleri veya davranışları isteyerek yapmalarını sağlama becerisi şeklinde tanımlamıştır.

Liderin hiçbir zorlama olmadan peşinden birçok kişiyi sürüklemesi araştırmacılar tarafından merak edilen (Elmuti vd., 2005:1018) ve ortaya koyduğu gizem sayesinde çözümlendikçe önemli katk1lar sağlayabilecek bir kavramdır. Bu yüzdendir ki birçok yönüyle; "liderin özellikleri, liderlik teorileri, liderlik davranış modelleri, liderin kullandiğı güç kaynakları ve liderlik yönelimleri" ele alınmıştır. Bu konuların her biri birbirini tamamlayan parçaları ifade etmektedir. İlk çalışmalarda liderin özellikleri üzerinde durulmuş olsa da grup üyelerinin tatminine ve iş veriminin artırılmasında liderin hangi davranışı sergilediği, sergilediği davranışların hangi durumlarda kabul gördüğü yapılan çalışmalar sonrasında ortaya çıkarılmaya çalışılmıştır.

Tarihsel süreçte liderlik kavramının zamana, durum ve koşullara göre büyük ölçüde değişikliklere uğradığı gözlenmektedir (Hodgetts ve Luthans, 2013'ten akt.: Şimşek ve Garipoğlu, 2016:83). Liderlerin sergilediği davranışlar üzerine "her zaman ve her yerde geçerli tek ve iyi bir liderlik tarzının olmadiğı" ifade edilmiştir (Yenel, 2018:299). Etkili bir liderlik anlayışının ortaya koyulması için ise Bolman ve Deal (1991) grubu amacına ulaştıran, amacına ulaştırırken de sorunları tanımlamak ve çözmek için kullandıkları farklı yöntemleri liderlik yönelimleri olarak ifade etmiştir. Lider ve liderlik yönelimleri, yaşanan hızlı değişimle birlikte rekabet boyutunun farklılaşması sonucu doğru kullanıldığında grup birlikteliği ve iş verimi bakımından önemli farklara etki edecek hususlardır. Bolman ve Deal (1991) örgütleri ve liderliği anlamak için dört çerçeve modelini geliştirmiştir. Bunlar; yapısal, insan kaynağı, politik ve semboliktir (Bolman ve Deal, 1991:511).

Dört çerçeve modelinde yapısal çerçeve için; sosyoloji disiplininden çıkarım yaptıklarını ifade etmişlerdir. Bu çerçevenin hedefleri ve amacı vurguladığına dikkat çekmişlerdir. Etkili bir örgütte hedeflerin net bir şekilde tanımlandığını, çalışanlara ise belirli roller verilerek, kurallar ve politikalar boyunca emir kumanda yoluyla çeşitli aktiviteleri koordine edildiğini belirtmişlerdir. Yapısal bakış açısına sahip liderler açık talimatlar verir, yeni politika ve kurallar veya yeni yapılanma boyunca örgüt problemlerini çözmeyi amaçlar. Sonuçlar için kişileri sorumlu tutar (Bolman ve Deal, 1991:512).

İnsan kaynakları çerçevesini çizerken, psikoloji ve örgütsel davranış alanlarından yararlanmışlardır. İnsanların ihtiyaçlarına odaklanmışlar buna ilaveten çalışanların temel ihtiyaçlarını karşılayan örgütlerin karşılamayan örgütlere kıyasla daha iyi çalışacaklarını ifade etmişlerdir. İnsan kaynakları liderleri ilişkilere ve duygulara değer verir. Bu ilişkileri güçlendirmek ve kolaylaştırma yoluyla liderlik etmeye çalışırlar. Kişiler arasındaki ya da bireylerdeki problemleri tanımlamak niyetindedirler. Kişiye uygun örgüt, örgüte uygun kişi ayarlamanın yoluna bakarlar (Bolman ve Deal, 1991:512).

Politik bakış açısı çerçevesine göre, örgüt amaçlarının yerine bireysel ve grup çıkarlarını vurgular. Siyaset biliminden beslenerek kıt kaynaklar için sürekli bir rekabetten ve farklı çıkarların olduğunu varsayar. Politik liderler gerçekliğe ve pragmatizme değer veren yandaşlar ve arabuluculardır (Bolman ve Deal, 1991:514). Bu liderler görüşme ve pazarlık yöntemini kullanırlar (Dereli, 2003:32).

Sembolik Çerçeve ise, kavramları ve görüntüleri çoğunlukla antropoloji alanı olan birçok disiplin ile sentezlemektedir. Örgütlenmeler insan davranışlarını gizlice şekillendiren bununla birlikte ortak bir misyon, kimlik duygusu, sembollerin ve örgüt kültürün gelişmesine katkı sağlamaktadır. Sembolik liderler sergiledikleri ve karizmatik duruşlarıyla coşku ve bağlılık duygusu aşılarlar. Bu tür liderler törenlere, hikâyelere, kutlamalara ve diğer sembolik biçimlere özen gösterirler (Bolman ve Deal, 1991:514).

Bolman ve Deal'ın dört çerçeve modeli ele alındığunda, yapısal çerçeve; liderliğin örgütleme ve planlama boyutunu temsil etmektedir. İnsan kaynakları çerçevesi; liderlik ile ilgili olarak örgütün insan yani çalışan 
(istihdam edilenler) boyutunu ortaya koymaktadır. Üçüncü unsur olan politik çerçeve; güç dinamiklerini, uzlaşma ve çatışma stratejilerini kapsamaktadır. Sembolik çerçeve ise; işe amaç ve anlam katan örgüt kültürüne dair perspektifleri temsil etmektedir (Şimşek ve Garipoğlu, 2016:83). Etkili bir liderin birden fazla çerçeveyi etkin bir şekilde kullanabilen liderler olduğuna vurgu yapmıştır (Dereli, 2003:33).

Liderlik yönelimi ile ilgili son dönemlerde yerli ve yabancı çalışmaların (Mujtaba, 2019; Igbinakhase ve Naidoo, 2019; Nguyen vd., 2019; Carrillo, 2019; Miska ve Mendenhall, 2018; Han vd., 2018; Kim vd., 2018; Cengiz ve Güllü, 2018; Özdemir, 2018; Özdemir vd., 2018; Özmen ve Şentürk, 2018; Cansoy ve Tofur, 2017; Acar, 2014; Arslan ve Uslu, 2014; Özkan, 2012; Çelik ve Sümbül, 2008; Akbaba ve Erenler, 2008; Taşkıran, 2006; Drocher,1997; Clark ve Clark, 1990) olduğu göze çarpmaktadır. Bu çalışmalarda ölçme aracı olarak Liderlik Yönelimleri Ölçeği (LYÖ) kullanılmıştır.

Bolman ve Deal (1991) tarafından Amerika Birleşik Devletleri’nde 1331 kişi ve Singapur'da 1238 kişiye uygulanarak geliştirilen Liderlik Yönelimleri Ölçeği’nde (LYÖ) toplam 23 madde bulunmaktadır. Thompson (2005) bu ölçek üzerinde çalışarak mevcut halini yeniden uyarlamıştır. Ölçeğe ait her bir alt boyuta ikişer yeni madde daha ekleyerek mevcut yapıdaki ölçme aracının madde sayısını sekize, toplamda ise 32'ye çıkarmıştır. Ölçeğin Türkçeye uyarlaması ilk olarak Dereli (2003) tarafından yapılmıştır. Daha sonra Özcan ve Balyer (2013) tarafından Liderlik Oryantasyon Ölçeği (LOÖ) olarak tekrar Türkçeye uyarlanmıştır. Liderlik Yönelimleri Ölçeği, örgüt ikliminin belirlenmesi amacıyla geliştirilmiştir. Dolayısıyla bu ölçeğin maddeleri de örgüt personellerine uygun olarak yazılmıştır. Buradan yola çıkılarak, Liderlik Yönelimleri Ölçeği'nin (LYÖ) maddeleri her örneklem üzerinde kullanılmaya uygun olmamasından dolayı her örneklem grubu üzerinde kullanılmaya uygun genel bir ölçme aracı geliştirmeye ihtiyaç duyulmuştur. Çok Yönlü Liderlik Yönelimleri Ölçeği (ÇYLYÖ) ile bireylerin liderlik yönelimlerinin belirlenmesine ilişkin, güvenirlik ve geçerlik çalışmaları yapılmış bir ölçme aracı geliştirilmesi amaçlanmıştır.

\section{2. ÇOK YÖNLÜ LIDERLIKK YÖNELIMLERİ ÖLÇEĞİ GEÇERLIKK-GÜVENIRLİK UYGULAMASI}

Çalışmanın bu kısmında, yapılan araştırmanın modeli, ilgili çalışma grubu, yapılan çalışmaya esas veri toplama aracının geliştirilme süreci ile verilerin toplanması ve analizine ilişkin bilgiler ele alınmıştır.

\section{1. Çalıșma Grubu}

Çok Yönlü Liderlik Yönelimleri Ölçeği'nin (ÇYLYÖ) güvenirlik ve geçerlik çalışmaları, 2018-2019 Eğitim yılı bahar döneminde Gazi Üniversitesi ile Hacı Bayram Veli Üniversitesi bünyesinde yer alan Spor Bilimleri Fakültesi, Sağlık Bilimleri Fakültesi, Eğitim Fakültesi, Edebiyat Fakültesi, Fen Fakültesi, Mimarlık Fakültesi, Mühendislik Fakültesi ve İktisadi ve İdari Bilimler Fakültesi'nde öğrenim gören toplam 503 üniversite öğrencisi üzerinde yapılmıştır. Çalışma grubunun seçimi yapılırken "amaçlı örnekleme yöntemlerinden" birisi olan "kolay ulaşılabilir örnekleme yöntemi" tercih edilmiştir. Bu yöntemde araştırmacı, kendisine yakın olan, dolayısıyla da erişilmesi kolay olan bir durumu seçmektedir (Yıldırım ve Şimşek, 2011:105). Yapılan seçim neticesinde ortaya çıkan çalışma grubu cinsiyet olarak \%52,9'u ( $\mathrm{n}=266)$ kadınlardan, \%47,1'i $(\mathrm{n}=237)$ ise erkeklerden oluşmaktadır. Katılımcılar, yapılan araştırmaya gönüllülük ilkesine göre dahil edilmiştir. Balcı (2005), Tezbaşaran (2008) ve Tavşancıl'a (2014) göre, çalışmanın örneklem büyüklüğünün ölçekte yer alan toplam madde sayısının beş (5) katı kadar olması gerekmektedir. Buna göre çalışma grubunun, güvenirlik ve geçerlik işlemleri için yeterli sayıda olduğu söylenebilir. Seçilen çalışma grubunun fakültelere ve cinsiyete göre dağılımları Tablo 1'de gösterilmiştir. 
Tablo 1: Çalışma Grubunun Fakültelere ve Cinsiyete Göre Dağılımı

\begin{tabular}{ccc}
\hline Fakülte & Kadın (n1) & Erkek (n2) \\
\hline Spor Bilimleri Fakültesi & 40 & 32 \\
\hline Sağlık Bilimleri Fakültesi & 27 & 28 \\
\hline Eğitim Fakültesi & 45 & 38 \\
\hline Fen Fakültesi & 22 & 28 \\
\hline İktisadi ve İdari Bilimler Fakültesi & 58 & 35 \\
\hline Mimarlık Fakültesi & 17 & 27 \\
\hline Mühendislik Fakültesi & 25 & 26 \\
\hline Edebiyat Fakültesi & 32 & $\mathbf{2 3 7}$ \\
\hline Toplam (n1+n2)=503 üniversite & $\mathbf{2 6 6}$ & \\
\hline
\end{tabular}

Kaynak: Yazarlar tarafından hazırlanmıştır.

\section{2. İşlem}

Ölçek geliştirmede öncelikle ölçülmesi amaçlanan kavramın kuramsal alt yapısının ve ölçeğin kullanılacağı hedef kitlenin tespit edilmesi gerekmektedir (De Vellis, 2014:42). Çalışmada ölçülmesi hedeflenen özelliğin kuramsal yapısının belirlenmesi için yurt içinde ve yurt dışındaki literatürde, "liderlik, liderlik yönelimleri" anahtar kelimeler kullanılarak özellik tanımlanarak 52 maddelik bir madde havuzu oluşturulmuştur. $\mathrm{Bu}$ maddeler hazırlanırken Bolman ve Deal (2014) tarafından yazılan "How Great Leaders Think?" isimli kitapta yer alan 4 boyutlu liderlik kuramından ve Bolman ve Deal (1991) tarafından geliştirilen ve Dereli (2003) tarafından Türkçeye uyarlanan Liderlik Yönelimleri Ölçeği'nden yararlanılmıştır. Oluşturulan bu maddeler tutarlılık yönüyle Spor Yöneticiliği Bölümü ve Ölçme Değerlendirme Bölümü’nden alan uzmanlarına, dil ve anlam yönüyle de dil uzmanlarına gösterilmiştir. Uzman görüşünden sonra son düzeltmeler yapılarak 43 maddelik taslak ölçek formu oluşturulmuş ve deneme uygulamasına hazır hale getirilmiştir. Bu aşamada maddelerin kapsam geçerliğinin sağlanmasına çalışılmıştır. "Kapsam geçerliği, bir bütün olarak ölçeğin ve ölçekteki her bir maddenin maksada ne derece hizmet ettiği ile ilgilidir" (Tekin, 2004:45). Başka bir deyişle kapsam geçerliliği, ölçekte bulunan maddelerin ölçme amacına uygun olup olmadığı, ölçülecek alanı temsil edip etmeme sorunu ile alakalı olup, uzman görüşü sonucunda belirlenir (Karasar, 2014:142). Uzman görüşleri neticesinde 43 maddeye düşün ölçek, uygulanması hedeflenen gruptan 25 üniversite öğrencisine bizzat araştırmacı tarafından uygulanıp ölçek maddelerinin bütün katılımcılarda aynı anlamı ifade etme düzeyi, maddelerin açık ve anlaşılır olması sınanmıştır. Uzman görüşleri ve yapılan ön uygulama sonucunda 7 madde ölçekten çıkarılmasıyla 36 maddelik denemelik ölçeğe son hali verilmiştir. Ölçek geliştirme çalışmalarında asıl amaç, verilen tüm çaba ve emek sonucunda daha güvenilir ve geçerli bir ölçek geliştirmektir (Tezbaşaran, 2008:44). Bu çalışmada yapılan tüm işlemlerin amac1, bir ölçeğin temel özelliğini oluşturan geçerlik ve güvenilirliğin sağlanmasıdır (Büyüköztürk, 2014:82).

Bu ölçek, çalışmaya dahil olan kişinin kendisi hakkında bilgi vermesine dayanan (self-report) bir ölçme aracıdır. Katılımcıların sorulara (maddelere) verecekleri tepkileri değerlendirmek amacı ile çalışmada 5'li Likert tipi dereceleme kullanılmıştır. Ölçek formundaki maddeler "Tamamen Katılmıyorum", "Katılmıyorum", "Kararsızım", "Katıllyorum", "Tamamen Katıllyorum" şeklinde sıralanmıştır. Bu sıralamaya uygun olarak ta "1", "2", "3", "4" ve "5" şeklinde puanlanmıştır. 


\subsection{Verilerin Toplanması}

Çalışmanın verileri 2018-2019 eğitim-öğretim yılı bahar döneminde toplanmıştır. Uygulama yapılmadan önce veri toplanacak fakülte, bölüm ve anabilim dallarından gerekli izinler alınmıştır. Katılımcılar tarafından ölçeklerin doldurulma işlemi yaklaşık 10-15 dakikada gerçekleştirilmiştir. Ölçekler doldurulmadan önce katılımcılara ölçeğin amacına dair gerekli açıklamalar yapılmıştır. Ölçek, Gazi Üniversitesi ve Hacı Bayram Veli Üniversitesi'nin farklı fakültelerinde öğrenim gören toplam 503 bireye uygulanmıştır. Analiz işlemine geçmeden doldurulan ölçekler incelenmiş ve analize uygun olmayan 7 ölçek analize dahil edilmemiştir. Böylece kalan 497 ölçek üzerinde analiz yapılmıştır.

\subsection{Verilerin Analizi}

Çalışmadan elde edilen veriler SPSS 22 ve Lisrel 8.8 paket programları kullanılarak gerekli analizler yapılmıştır. Yapı geçerliliği aşamasında öncelikli olarak Açımlayıcı Faktör Analizi (AFA) uygulanmış, AFA sonucunda oluşan yapının doğrululuğu test etmek için ise Doğrulayıcı Faktör Analizi (DFA) yapılmıştır. Daha sonra maddelerin ayırt ediciliğini belirleme maksadıyla düzeltilmiş madde test korelasyonu ve \%27'lik alt-üst grup karşılaştırmaları incelenmiştir. Madde analiz değerlendirme işleminden sonra, yapının güvenirliliği için de Cronbach Alfa iç tutarlılık katsayısı ile incelenmiştir.

\section{3. ÇALIŞMANIN BULGULARI}

Bu bölümde "Çok Yönlü Liderlik Yönelimleri Ölçeği"'nin (ÇYLYÖ) güvenirlik ve geçerliliğine kanıt oluşturmak amacıyla yapılan istatistiksel işlemlere yer verilmiştir.

\subsection{Yapı Geçerliği}

Yapı geçerliliği, ölçeğin ölçmek istediği teorik yapının ölçülebilme derecesi olarak tanımlanır ve ölçme aracında bulunan her bir maddenin birbirleriyle olan ilişkisi ortaya konulur (Seçer, 2013:128). Çok Yönlü Liderlik Yönelimleri Ölçeği'nden (ÇYLYÖ) elde edilen ölçümlerin yapı geçerliliğini test etmek için Açımlayıcı Faktör Analizi (AFA) ve Doğrulayıcı Faktör Analizi (DFA) uygulanmıştır.

\subsubsection{Açımlayıcı Faktör Analizi (AFA)}

AFA, ölçme aracında aynı yapıyı ölçen maddelerin bir araya toplanması ile daha az madde ile açıklamayı hedefleyen istatistiksel bir tekniktir (De Vellis, 2014:42; Tezbaşaran, 2008:44). Çalışma grubu ile elde edilen verilerin faktör analizine uygun olup olmadığ Kaiser-Mayer-Olkin (KMO) katsayısı ve Bartlett testi ile açıklanabilir (Büyüköztürk, 2014:81). Uzmanlara göre KMO değerinin 0,50 kabul edilebilir, 0,60 orta, 0,70 iyi, 0,80 çok iyi ve 0,90 ise mükemmel olarak tanımlanmaktadır (Şeker vd., 2004:107). Verilerin faktör analizine uygun olması için KMO değerinin en az 0,60 olması ve Barlett testinin de anlamlı olması gerekmekte (Tavşancıl, 2014:65; Çokluk vd., 2012:185) olup, verilerin çok değişkenli normal dağılımdan geldiğini ve değişkenler arasında faktörleştirme tekniklerinin kullanılabileceği göstermektedir (De Vellis, 2014:43; Fraenkel ve Wallen, 2000:48; Kline, 1998:35). Bu çalışmada, Kaiser-Mayer-Olkin (KMO) değeri 0.87 ve BarletSphericity testi ki kare değeri ise 2735,321 $(\mathrm{p}<0.01)$ olarak bulunmuştur. Çıkan bu değerlerin ölçme aracı ile elde edilen bu verilerin faktör analizi için çok iyi derecede uygun olduğu ifade edilebilir.

AFA sonucunda, faktör sayısına karar verilirken her bir faktörün toplam varyansa sağladığı katkı ve KaiserGuttman ilkesine göre özdeğeri 1'den büyük olan örtük değişkemler dikkate alınır. Ayrıca, ÇYLYÖ’nin faktör yapısının analizi sırasında faktör yapılarının yorumlanmasının kolay olması için faktör içinde birbirleriyle yüksek ilişkisi olan maddeleri bir araya getirmek için döndürme (rotation) tekniği kullanılmıştır. Çalışmada, ölçülmesi amaçlanan özelliğin alt boyutlarının ilişkisiz olduğu ön görüldüğünden dolayı, varimax döndürme tekniği kullanılmıştır.

Uzmanların birçoğuna göre, maddelerin faktör içindeki yük değerlerinin 0,30' dan yüksek olması gerekmektedir (De Vellis, 2014:42; Tavşanc1l, 2014:65; Seçer, 2013:128; Büyüköztürk vd., 2012:142). Bu çalışmada, faktör yük değerleri 0,40 olarak belirlenmiştir. Faktör yük değeri 0,40 'tan düşük olan ve bir maddenin iki faktöre yüksek yük değeri verdiğinde, yük değerleri arasındaki farkın binişiklik olmaması için en az 0,10 olmasına dikkat edilmiş (Büyüköztürk, 2014:82) ve faktör analizinde aynı yapıyı ölçmeyen 19 madde $(5,8,10,16,17$, 
DURSUN, Mücahit, GÜNAY, Mehmet ve YENEL, Fatih - Çok Yönlü Liderlik Yönelimleri Ölçeği (ÇYLYÖ): Geçerlik ve Güvenirlik Çalışması

$18,22,23,25,26,27,29,30,32,33,35)$ ölçme aracından çıkarılması ile birlikte toplam 19 madde ve 4 alt boyuttan oluşan nihai ölçme aracı elde edilmiştir. Açımlayıcı Faktör Analizi (AFA) sonuçları Tablo 2'de verilmiştir.

Tablo 2. Çok Yönlü Liderlik Yönelimleri Ölçeğinin Açımlayıcı Faktör Analizi Sonuçları

\begin{tabular}{|c|c|c|c|c|}
\hline Alt Boyutlar & Maddeler & $\begin{array}{l}\text { Faktör } \\
\text { Yükleri }\end{array}$ & $\begin{array}{c}\text { Açıkladı̆̆ı \% } \\
\text { Varyans }\end{array}$ & $\begin{array}{c}\text { Toplam \% } \\
\text { Varyans }\end{array}$ \\
\hline \multirow{5}{*}{$\begin{array}{c}\text { Politik } \\
\text { Liderlik }\end{array}$} & İnsanları harekete geçirme yeteneğine sahibim. & 627 & \multirow{5}{*}{$\begin{array}{l}\stackrel{\infty}{+} \\
\text { } \\
0\end{array}$} & \multirow{19}{*}{$\begin{array}{l}\hat{8} \\
\infty \\
\text { in }\end{array}$} \\
\hline & 9. İnsanları ikna etmede başarılıyım. & ,712 & & \\
\hline & 13. Güç sahibi insanların desteğini almada başarılıyım. & ,776 & & \\
\hline & 14. İnsanları etkileme yeteneğine sahibim. & 809 & & \\
\hline & 15. İnsanlar için ilham kaynağıyım. & 616 & & \\
\hline \multirow{5}{*}{$\begin{array}{c}\text { İnsan } \\
\text { Kaynaklı } \\
\text { Liderlik }\end{array}$} & 2. Başkalarının sorunlarına karşı duyarlıyım. & 679 & \multirow{5}{*}{$\begin{array}{l}0 \\
a \\
\text { ct }\end{array}$} & \\
\hline & 12. Başkasının fikirlerini önemserim. & ,735 & & \\
\hline & 19. İnsanlar arasındaki sorunları çözme konusunda gayretliyim. & 609 & & \\
\hline & 21. İnsanlara yardım etmeyi severim. & ,722 & & \\
\hline & 31. İyi bir dinleyiciyim. &, 594 & & \\
\hline \multirow{5}{*}{$\begin{array}{c}\text { Karizmatik } \\
\text { Liderlik }\end{array}$} & 20. Yaratıcı bir insanımdır. &, 521 & \multirow{5}{*}{$\begin{array}{l}\text { ล̃ } \\
\text { ป }\end{array}$} & \\
\hline & 24. Kendimi karizmatik bulurum. & 677 & & \\
\hline & 28. Heyecan verici yeni fikirler yaratırım. &, 563 & & \\
\hline & 34. Zorluklara rağmen başarıya ulaşırım. & 653 & & \\
\hline & 36. Doğru kararlar vermede başarılıyım. & ,666 & & \\
\hline \multirow{4}{*}{$\begin{array}{c}\text { Yapısal } \\
\text { Liderlik }\end{array}$} & 1. Mantıklı düşünürüm. &, 526 & \multirow{4}{*}{$\begin{array}{l}\sqrt{\sigma} \\
\infty \\
0 \\
0\end{array}$} & \\
\hline & Dikkatli plan yaparım. & 695 & & \\
\hline & Planlanan işlerin zamanında bitirilmesine önem veririm. & 669 & & \\
\hline & 11. Problemleri mantıklı düşünerek çözerim. & 650 & & \\
\hline
\end{tabular}

Kaynak: Yazarlar tarafından hazırlanmıştır.

Tablo 2'de yapılan açımlayıcı faktör analiz varimax dönüştürmesi sonucunda oluşan 4 faktör yapısının varyansın \%52,807'ni açıkladığı tespit edilmiştir. Sosyal bilimlerde varyans oranlarının \%40 ile \%60 arası olması yeterli kabul edilir (Tavşancıl, 2014). Buna göre açıklanan varyans oranının yeterli düzeyde olduğu görülmektedir. "Politik Liderlik" alt boyutunun faktör yükleri 0.61-0.80, "İnsan Kaynaklı Liderlik" alt boyutunun faktör yükleri 0.59-0.73, "Karizmatik Liderlik" alt boyutunun faktör yükleri 0.52-0.67 "Yapısal Liderlik" alt boyutunun faktör yükleri 0.52-0.69 arasında değişmektedir.

\subsubsection{Doğrulayıcı Faktör Analizi}

AFA sonrası oluşan modelin, yapı geçerliliğini doğrulamak için DFA yapılır (Kline, 1998:35). AFA VE DFA ölçek geliştirme sürecinde birbirlerinin tamamlayıcısı olarak birlikte kullanılırlar (Erkuş, 2014:98). DFA sürecinde test edilen modelin yeterliliğinin sınanması için bir çok uyum indeksi kullanılmaktadır (Büyüköztürk vd., 2014:88). Bunlar içinde en sık kullanılanları, ki-kare uyum değeri $\left(\mathrm{x}^{2 / \mathrm{sd}}\right)$, Uyum İyiliği İndeksi (Goodness of Fit Index, GFI), Karşılaştırmalı Uyum İndeksi (Comparative Fit Index, CFI), Normlaştırılmış Uyum Indeksi 
(Normed Fit Index, NFI), Yaklaşık Hataların Ortalama Karekökü (Root Mean Square Error of Approximation, RMSEA), Standardize edilmiş ortalama hataların karekökü (Standardized Root Mean Square Residual SRMR) ve Ortalama Hataların Karekökü (Root Mean Square Residuals, RMR) uyum indeksleri incelenmiştir. Yapılan çalışmada uyum indeks değerleri Tablo 3'te verilmiştir.

Tablo 3. ÇYLYÖ’nin Doğrulayıcı Faktör Analizine İlişkin Uyum İndeks Değerleri

\begin{tabular}{|c|c|c|c|}
\hline Değerler & Normal Değer & Kabul Edilebilir Değer & LYÖ \\
\hline$X^{2} / \mathrm{sd}$ & $<2$ & $<5$ & $\mathbf{2 . 7 2}$ \\
\hline GFI & $>0.95$ & $>0.90$ & $\mathbf{0 . 9 2}$ \\
\hline CFI & $>0.95$ & $>0.90$ & $\mathbf{0 . 9 6}$ \\
\hline NFI & $>0.95$ & $>0.90$ & $\mathbf{0 . 9 3}$ \\
\hline AGFI & $>0.95$ & $>0.90$ & $\mathbf{0 . 9 0}$ \\
\hline RMSEA & $<0.05$ & $<0.08$ & $\mathbf{0 . 5 9}$ \\
\hline SRMR & $<0.05$ & $<0.08$ & $\mathbf{0 . 4 8}$ \\
\hline RMR & $<0.05$ & $<0.08$ & $\mathbf{0 . 3 3}$ \\
\hline
\end{tabular}

Kaynak: Hu ve Bentler, 1999; Schermelleh-Engel vd., 2003; Kline, 1998; Hooper ve Mullen, 2008.

Tablo 3'te ölçme aracına ilişkin uyum indeksleri; $\mathrm{x} 2 / \mathrm{sd}=2.72$, GFI=0.92, CFI=0.96, NFI=0.93, AGFI=0.86, RMSEA=0.06, $\mathrm{SRMR}=0,48$ ve $\mathrm{RMR}=0,33$ olarak bulunmuştur. Bu uyum indeksleri dikkate alındığında, 4 boyutlu teorik yapının toplanan verilerle doğrulandığı ifade edilebilir.

Şekil 1. Çok Yönlü Liderlik Yönelimleri Ölçeği Doğrulayıcı Faktör Analizi Sonuçları

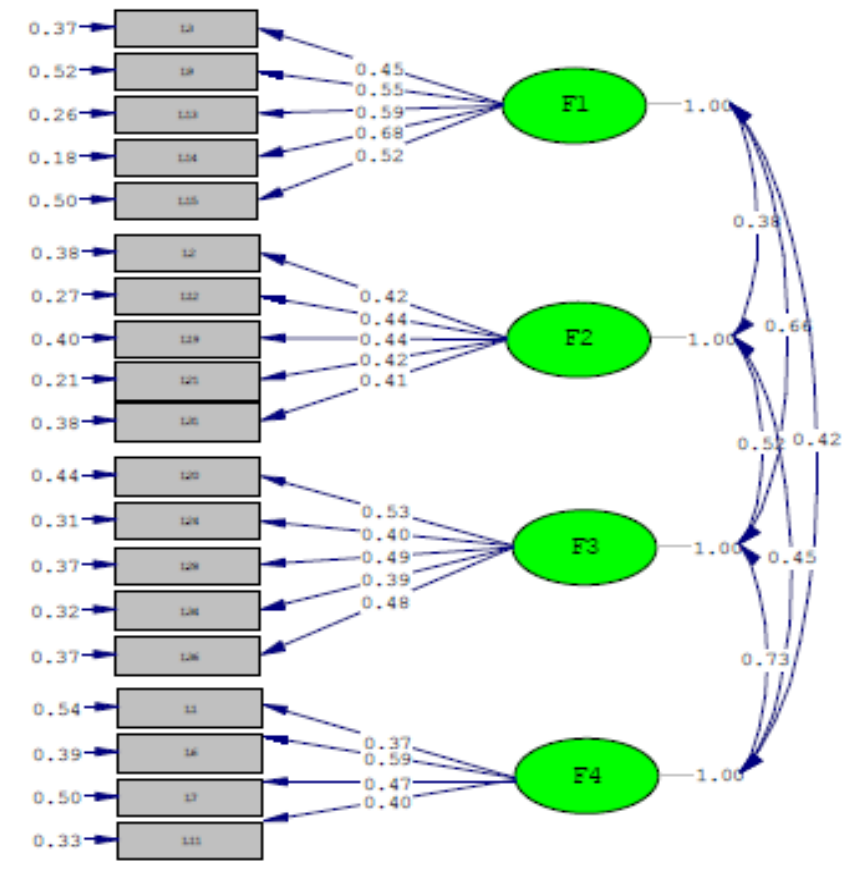


DFA sonucunda elde edilen 4 boyutlu modele ilişkin faktör yükleri Şekil 1'de yer almaktadır. Şekil 1, gözlenen değişkenler ile gizil değişkenler arasındaki regresif bağın "Politik Liderlik" alt boyutunda 0.45 ile 0.68 , "İnsan Kaynaklı Liderlik" alt boyutunda 0.41 ile 0.44, "Karizmatik Liderlik" alt boyutunda 0,39 ile 0,53 ve "Yapisal Liderlik" alt boyutunda ise 0.37 ile 0.59 arasında olduğunu göstermektedir. Bir ölçeğin yapı geçerliğine kanıt sağlamak için önerilen diğer bir yol ise o ölçeği oluşturan alt boyutlar arası korelasyonların hesaplanmasıdır (Şencan, 2005:253). Bu amaçla, ÇYLYÖ’nin alt boyutları arasındaki korelasyonları hesaplanmış ve sonuçlar Tablo 4'te verilmiştir.

Tablo 4. ÇYLYÖ’nin Alt Boyutları Arasındaki Korelasyon Değerleri

\begin{tabular}{|c|c|c|c|c|c|}
\hline \multicolumn{2}{|c|}{ Alt Boyutlar(n=497) } & Politik & İnsan Kaynaklı & Karizmatik & Yapısal \\
\hline \multirow{2}{*}{ Politik } & $\mathrm{r}$ & 1 &, $334^{* *}$ &, $536^{* *}$ &, $355^{* *}$ \\
\cline { 2 - 7 } & $\mathrm{p}$ & &, 000 &, 000 &, 000 \\
\hline \multirow{2}{*}{ İnsan Kaynaklı } & $\mathrm{r}$ &, $334^{* *}$ & 1 &, $395^{* *}$ &, $323^{* *}$ \\
\cline { 2 - 7 } & $\mathrm{p}$ &, 000 &, 000 &, 000 \\
\hline \multirow{2}{*}{ Karizmatik } & $\mathrm{r}$ &, $536^{* *}$ &, $395^{* *}$ & 1 &, $512^{* *}$ \\
\cline { 2 - 7 } & $\mathrm{p}$ &, 000 &, 000 &, 000 \\
\hline \multirow{2}{*}{ Yapısal } & $\mathrm{r}$ &, $355^{* *}$ &, $323^{* *}$ &, $512^{* *}$ & 1 \\
\cline { 2 - 7 } & $\mathrm{p}$ &, 000 &, 000 &, 000 &, \\
\hline
\end{tabular}

Kaynak: Yazarlar tarafindan hazırlanmıştır.

Tablo 4'te Ölçeğin alt boyutları arasındaki korelasyon değerlerine göre; tüm alt boyutlar arasında pozitif ve anlamlı ilişki tespit edilmiştir $(\mathrm{p}<0,01)$.

\subsection{Madde Analizi}

Çok Yönlü Liderlik Yönelimleri Ölçeği'ndeki verilerin madde analizleri, madde toplam test korelasyonu karşılaştııılmıştır. Yapılan madde analizindeki bulgular Tablo 5'de verilmiştir. Madde toplam test korelasyonu ile ölçekte bulunan her bir maddenin, ölçmek istediği özelliği ölçüp ölçmediğini ve ölçtüğü özellik bakımından kişileri ayırt edip etmediği test edilmiştir (Büyüköztürk vd., 2012:142). Bir ölçekteki maddenin madde toplam test korelasyonu düşükse, ölçekteki o maddenin özelliği ölçmediği ifade edilir (Karasar, 2014:142). Madde toplam test korelasyon puanı 0,30 ve üzeri olan maddelerin iyi derecede ayırt edici özelliğe sahip olduğu belirtilmektedir (Nunnally ve Benstein, 1994:145; Büyüköztürk, 2014:178; Erkuş, 2014:98). 
Tablo 5. Çok Yönlü Liderlik Yönelimleri Ölçeği Madde Analizi Sonuçları

\begin{tabular}{|c|c|c|c|c|}
\hline \multicolumn{2}{|c|}{ No } & Madde Toplam Test Korelasyonu & $\square$ & $\mathbf{S}$ \\
\hline \multirow{5}{*}{ 泀 } & 3 &, 573 & 3,97 & ,799 \\
\hline & 9 &, 554 & 3,51 & ,927 \\
\hline & 13 & ,646 & 3,84 &, 825 \\
\hline & 14 & ,726 & 3,89 & ,859 \\
\hline & 15 &, 522 & 3,46 & ,906 \\
\hline \multirow{5}{*}{ 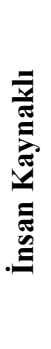 } & 2 & ,454 & 4,25 &, 815 \\
\hline & 12 &, 541 & 4,27 & ,779 \\
\hline & 19 &, 538 & 3,93 & 840 \\
\hline & 21 & ,585 & 4,48 & ,749 \\
\hline & 31 &, 552 & 4,08 &, 809 \\
\hline \multirow{5}{*}{ 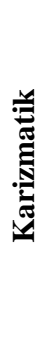 } & 20 & ,607 & 3,94 &, 890 \\
\hline & 24 & 600 & 4,07 & ,771 \\
\hline & 28 &, 598 & 3,85 & ,838 \\
\hline & 34 & ,620 & 4,15 & ,777 \\
\hline & 36 & ,603 & 3,84 & ,841 \\
\hline \multirow{4}{*}{ 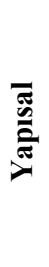 } & 1 & ,437 & 4,11 & ,868 \\
\hline & 6 & ,513 & 3,96 & ,898 \\
\hline & 7 & ,482 & 4,18 & ,920 \\
\hline & 11 & ,579 & 4,11 & ,803 \\
\hline
\end{tabular}

Kaynak: Yazarlar tarafından hazırlanmıştır.

Tablo 5'ye göre ölçekte yer alan maddelerin madde-toplam test korelasyon değerlerinin 0,43- ile 0,72 arasında değişmektedir. Başka bir ifadeyle ölçme aracında bulunan maddelerin her birinin, ölçeğin tamamıyla ilişkili ve uyumlu olduğu şeklinde yorumlanabilir.

Ölçme aracında yer alan her bir maddenin özelliği taşıyan ve taşımayan bireyleri ayır edip etmediği, toplam ölçek puanlarına göre belirlenmiş olan \%27 alt-üst grubun ortalama puanları arasındaki farklar t testi ile incelenmiş ve sonuçlar Tablo 6'de verilmiştir.

Tablo 6. \%27 Alt-Üst Gruplar Arasındaki Farklılıklara Ait T-Testi Sonuçları

\begin{tabular}{|c|c|c|c|c|c|}
\hline \multicolumn{2}{|c|}{ Maddeler } & $\square$ & Ss & df & t \\
\hline \multirow{2}{*}{ L3 } & Alt & 3,37 &, 76 & 270 & $16,075^{*}$ \\
\cline { 2 - 6 } & Üst & 4,64 &, 51 & & \\
\hline \multirow{2}{*}{ L9 } & Alt & 2,67 &, 75 & 270 & $18,914^{*}$ \\
\cline { 2 - 6 } & Üst & 4,30 &, 67 & & \\
\hline \multirow{2}{*}{ L13 } & Alt & 3,13 &, 75 & 270 & $18,171^{*}$ \\
\hline
\end{tabular}


DURSUN, Mücahit, GÜNAY, Mehmet ve YENEL, Fatih - Çok Yönlü Liderlik Yönelimleri Ölçeği (ÇYLYÖ): Geçerlik ve Güvenirlik Çalışması

\begin{tabular}{|c|c|c|c|c|c|}
\hline & Üst & 4,56 &, 51 & & \\
\hline \multirow{2}{*}{ L14 } & Alt & 3,10 &, 75 & 270 & $21,333^{*}$ \\
\hline & Üst & 4,71 & ,45 & & \\
\hline \multirow{2}{*}{ L15 } & Alt & 2,76 &, 80 & 270 & $16,135^{*}$ \\
\hline & Üst & 4,19 & ,65 & & \\
\hline \multirow{2}{*}{$\mathbf{L} 2$} & Alt & 3,71 &, 83 & 270 & $14,733 *$ \\
\hline & Üst & 4,85 &, 35 & & \\
\hline \multirow{2}{*}{ L12 } & Alt & 3,76 &, 74 & 270 & $15,574 *$ \\
\hline & Üst & 4,87 &, 36 & & \\
\hline \multirow{2}{*}{ L19 } & Alt & 3,38 &, 82 & 270 & $14,985^{*}$ \\
\hline & Üst & 4,63 &, 51 & & \\
\hline \multirow{2}{*}{ L21 } & Alt & 3,60 &, 71 & 270 & $15,253^{*}$ \\
\hline & Üst & 4,71 &, 47 & & \\
\hline \multirow{2}{*}{ L31 } & Alt & 3,97 & ,67 & 270 & $16,469^{*}$ \\
\hline & Üst & 4,96 &, 18 & & \\
\hline \multirow{2}{*}{ L20 } & Alt & 3,18 &, 86 & 270 & $16,911 *$ \\
\hline & Üst & 4,65 &, 52 & & \\
\hline \multirow{2}{*}{ L24 } & Alt & 3,58 &, 77 & 270 & $13,514 *$ \\
\hline & Üst & 4,65 &, 50 & & \\
\hline \multirow{2}{*}{ L28 } & Alt & 3,18 &, 78 & 270 & $15,978^{*}$ \\
\hline & Üst & 4,53 &, 59 & & \\
\hline \multirow{2}{*}{ L34 } & Alt & 3,65 &, 76 & 270 & $15,224^{*}$ \\
\hline & Üst & 4,79 & ,41 & & \\
\hline \multirow{2}{*}{ L36 } & Alt & 3,21 &, 82 & 270 & $15,456^{*}$ \\
\hline & Üst & 4,54 &, 55 & & \\
\hline \multirow{2}{*}{ L1 } & Alt & 3,51 & ,95 & 270 & $13,475^{*}$ \\
\hline & Üst & 4,74 & ,45 & & \\
\hline \multirow{2}{*}{ L6 } & Alt & 3,12 &, 84 & 270 & $20,598 *$ \\
\hline & Üst & 4,78 & ,41 & & \\
\hline \multirow{2}{*}{ L7 } & Alt & 3,38 & ,91 & 270 & $17,636^{*}$ \\
\hline & Üst & 4,85 &, 35 & & \\
\hline
\end{tabular}




\begin{tabular}{|c|c|c|c|c|c|}
\hline \multirow{2}{*}{ L11 } & Alt & 3,68 &, 84 & 270 & $12,637 *$ \\
\cline { 2 - 6 } & Üst & 4,71 &, 45 & & \\
\hline
\end{tabular}

Kaynak: Yazarlar tarafından hazırlanmıştır.

Ölçeğin \%27 alt ve üst gruplarının madde puan ortalamaları arasındaki farklara ilişkin analiz sonuçları incelendiğinde, $t$ değerlerinin 12,637 ile 21,333 aralığında değişim gösterdiği ve bu değerlerin anlamlı düzeyde (df:270, $\mathrm{p}<0,01)$ olduğu tespit edilmiştir. Elde edilen bulgular neticesinde ölçekte yer alan maddelerin her birinin, özellik kapsamında bireyler arası farklılıkları ortaya çıkarabildiği söylenebilir.

\section{3. Ölçeğin Güvenirliği}

Güvenilirlik, bir ölçeğin duyarlı, birbiriyle tutarlı ve kararlı ölçme sonuçları verebilme gücüdür (Tezbaşaran, 2008:44). Başka bir ifadeyle, değişik zamanlarda elde edilen cevaplar ile aynı zamanda elde edilen cevaplar arasındaki tutarlılıktır (Esentürk vd., 2019:68). Bu çalışmada, ölçeğin geneli ve alt boyutlarının güvenirlik hesaplamaları Cronbach Alfa iç tutarlılık katsayısı ile hesaplanmıştır. Güvenirlik analizinde Alpha değerinin en az 0.70 olmas1 gerektiği (Anderson, 1988:890; Kline, 1998:35; Peers, 1996:91) söylenmektedir. Faktör analizi sonrası elde edilen 4 alt boyut için Cronbach Alpha güvenirlik katsayıları Tablo 7’te verilmiştir.

Tablo 7. ÇYLYÖ’nin Alt Boyutlarına İlişkin İç Tutarlılık Katsayıları

\begin{tabular}{|c|c|}
\hline Alt Boyutlar & Cronbach Alpha ( $\boldsymbol{\alpha})$ \\
\hline Politik Liderlik &, 80 \\
\hline İnsan Kaynaklı Liderlik &, 73 \\
\hline Karizmatik Liderlik &, 74 \\
\hline Yapısal Liderlik &, 72 \\
\hline Ölçeğin Genel İç Tutarlılık Katsayısı &, 85 \\
\hline
\end{tabular}

Kaynak: Yazarlar tarafından hazırlanmıştır.

Tablo 7'de görüldügü gibi, analiz sonucunda ölçme aracının Cronbach Alfa güvenirlik katsayısı, ölçeğin geneli için 0.85 olarak bulunmuştur. Ölçeğin "Politik Liderlik" alt boyutunda bu değer 0.80, "İnsan Kaynaklı Liderlik" alt boyutunda 0,73, "Karizmatik Liderlik" alt boyutunda 0.74 ve "Yapısal Liderlik" alt boyutunda ise 0,72 olarak tespit edilmiştir. Güvenirlik analizi sonucunda ortaya çıkan bulgular, ölçeğin geneli ve alt boyutlarının oldukça güvenilir olduğunu ortaya koymuştur.

\section{TARTIŞMA VE SONUÇ}

$\mathrm{Bu}$ araştırmada, bireylerin liderlik yönelimlerini geçerli ve güvenilir olarak ölçebilen bir ölçme aracının geliştirilmesi amaçlanmıştır. ÇYLYÖ geliştirilirken, Bu maddeler hazırlanırken Bolman ve Deal (2014) tarafindan yazılan "How Great Leaders Think?" isimli kitapta yer alan 4 boyutlu liderlik kuramı temel alınarak 52 maddelik bir havuz oluşturulmuştur. Ortaya çıkan madde havuzu, uzman görüşleri ve pilot uygulama doğrultusunda 36 maddelik taslak forma dönüştürülmüştür.

Çok Yönlü Liderlik Yönelimleri Ölçeği'nden (ÇYLYÖ) elde edilen ölçümlerin yapı geçerliliğini test etmek için Açımlayıcı Faktör Analizi (AFA) ve Doğrulayıcı Faktör Analizi (DFA) uygulanmıştır. AFA öncesinde, çalışma grupları üzerinden toplanan verilerin faktörleşmeye uygun olup olmadığı değerlendirilmiştir. Çalışma grubundan gelen verilerin faktör analizi için uygun olup olmadığı Kaiser-Mayer-Olkin (KMO) katsayısı ve Bartlett testi ile açıklanabilir (Büyüköztürk, 2014:158). Bu çalışmada, Kaiser-Mayer-Olkin (KMO) değeri 0.87 ve Barlet-Sphericity testi ki kare değeri ise 2735,321 ( $<<0.01$ ) olarak bulunmuştur.

Çıkan bu değerlerin ölçme aracı ile elde edilen bu verilerin faktör analizi için çok iyi derecede uygun olduğu ifade edilebilir. AFA sonucunda toplam varyansın \%52,80'ini açıklayan 19 madde ve 4 alt boyuttan oluşan bir yapı elde edilmiştir. Alt boyutlar "Politik Liderlik", "İnsan Kaynaklı Liderlik", "Karizmatik Liderlik" ve 
"Yapısal Liderlik" olarak isimlendirilmiştir. "Politik Liderlik" boyutu 5 maddeden $(3,9,13,14,15)$ oluşmakta ve toplam varyansın \%16,248'ini açıklamaktadır. "Politik Liderlik" boyutunda yer alan maddelerin faktör yükleri 0.61 ile 0.80 arasında değişmektedir. "İnsan Kaynaklı Liderlik" boyutu, 5 maddeden $(2,12,19,21,31)$ oluşmakta ve toplam varyansın \%12,916'sını açıklamaktadır. "İnsan Kaynaklı Liderlik" boyutunda yer alan maddelerin faktör yükleri 0.59 ile 0.73 arasında değişmektedir. "Karizmatik Liderlik" boyutu, 5 maddeden $(20,24,28,34,36)$ oluşmakta ve toplam varyansın \%12,792'ini açılamaktadır. "Karizmatik Liderlik" boyutunda yer alan maddelerin faktör yükleri 0.52 ile 0.67 arasında değişmektedir. "Yapısal Liderlik" boyutu ise, 4 maddeden $(1,6,7,11)$ oluşmakta ve toplam varyansın \%10,852'ini açıklamaktadır. "Yapısal Liderlik" boyutunda yer alan maddelerin faktör yükleri 0.52 ile 0.69 arasında değişmektedir.

Teorik olarak kurgulanan ölçüm modelinin veriler tarafından doğrulanıp doğrulanmadığı DFA ile sınanmıştır. ÇYLYÖ’ye ilişkin uyum indeksi değerleri x2/sd=2.72, CFI=0.96, GFI=0.82, AGFI=0.86, RMSEA=0,06, NFI= $0,93, \mathrm{SRMR}=0,48$ ve $\mathrm{RMR}=0,33$ olarak bulunmuştur. DFA'dan elde edilen uyum indekslerinin, 4 alt boyutlu yapıyı doğrular seviyede olduğu tespit edilmiştir. DFA sonucunda elde edilen faktör yüklerinin, "Politik Liderlik" boyutunda 0.45 ile 0.68, "Insan Kaynaklı Liderlik" boyutunda 0.41 ile 0.44 ve "Karizmatik" boyutunda 0.39 ile 0.53 ve "Yapısal Liderlik" boyutunda ise 0,37 ile 0,59 arasında olduğu tespit edilmiştir. Nitekim DFA sonucunda elde edilen faktör yüklerinin büyük etki büyüklüklerini yansıttığı söylenebilir. Yapı geçerliği kapsamında uygulanan AFA ve DFA sonucunda ulaşılan bulgular, ölçme aracının yapı geçerliğine dair kanıt sağlandığını göstermektedir.

ÇYLYÖ'den elde edilen verilerin madde analizleri, madde toplam test korelasyonu ve \%27 alt-üst grupları karşılaştırılarak incelenmiştir. İlk olarak madde toplam test korelasyonu gerçekleştirilmiştir. Çalışmada, maddetoplam test korelasyon değerlerinin 0,43 ile 0,72 arasında değişmektedir. Başka bir ifadeyle ölçme aracında bulunan maddelerin her birinin, ölçeğin tamamıyla ilişkili ve uyumlu olduğu şeklinde ifade edilebilir. Ölçme aracında yer alan her bir maddenin özelliği taşıyan ve taşımayan bireyleri ayır edip etmediği, toplam ölçek puanlarına göre belirlenmiş olan \%27 alt-üst grubun ortalama puanları arasındaki farklar t- testi (Kılıç vd., 2014) ile incelenmiştir. Çalışmada, t değerlerinin 12,637 ile 21,333 aralığında değişim gösterdiği ve bu değerlerin anlamlı düzeyde (df:270, p<0,01) olduğu tespit edilmiştir. Elde edilen bulgular neticesinde ölçekte yer alan maddelerin her birinin, özellik kapsamında bireyler arası farklılıkları ortaya çıkarabildiği söylenebilir.

$\mathrm{Bu}$ çalışmada ölçeğin geneli ve alt boyutlarına yönelik Cronbach Alfa İç Tutarlık Katsayısı hesaplanmıştır. Analiz sonucunda ölçme aracının Cronbach Alfa güvenirlik katsayısı, ölçeğin geneli için 0.85 olarak bulunmuştur. Ölçeğin "Politik Liderlik" alt boyutunda bu değer 0.80 , "İnsan Kaynaklı Liderlik" alt boyutunda 0.73, "Karizmatik Liderlik" alt boyutunda 0.74 ve "Yapısal Liderlik" alt boyutunda ise 0,72 olarak tespit edilmiştir. Güvenirlik Analizi sonucunda ortaya çıkan bulgular, ölçeğin geneli ve alt boyutlarının güvenilir olduğunu ortaya koymuştur. Yapılan tüm analizlerden elde edilen bulgular ÇYLYÖ'nin, ölçmeye çalıştığı özelliği başka özelliklerle karıştırmadan doğru şekilde ölçebildiğini ve ölçmeden ölçmeye duyarlı ve tutarlı ölçümler gerçekleştirebildiğini göstermektedir.

Çok Yönlü Liderlik Yönelimleri Ölçeğinde (ÇYLYÖ) yer alan maddeler “Tamamen Katılmıyorum” ile "Tamamen Katılıyorum" aralığında 5'li likert tipinde derecelendirilmektedir. Ölçekte ters puanlanan madde bulunmamaktadır. Ölçek alt boyutlar kapsamında değerlendirilmektedir. Ölçeğin alt boyutlarından elde edilen puanların yüksek oluşu bireyin o liderlik yönelimine eğiliminin de yüksek olduğunu göstermektedir. Geliştirilen ölçek kaynak gösterilmesi halinde izin alınmadan kullanılabilir.

\section{KAYNAKÇA}

ANDERSON, Lorin Woodrow (1988), "Attitudes and Their Measurement", Educational Research, Methodology and Measurement: An International Handbook (Ed. J. P. Keeves), Pergamon Press, New York, ss.885-895.

AYDIN, Mustafa (2013), Eğitimde Örgütsel Davranış, Gazi Kitapevi, Ankara.

BALCI, Ali (2005), Sosyal Bilimlerde Araştırma Yöntem, Teknik ve İlkeler, Pegem Yayınları, Ankara, 5.Bask1.

BAŞARAN, İbrahim Ethem (2004), Yönetimde İnsan İlişskileri, Nobel Yayın Dağıtım, Ankara.

BOLMAN, Lee G. ve DEAL, Terrence (1991), “Liderlik ve Yönetim Etkinliği: Çok Çerçeveli, Çok Sektörlü Bir Analiz”, İnsan Kaynakları Yönetimi Dergisi, S.30(4), ss.509-534. 
BOLMAN, Lee G. ve DEAL, Terrence (2014), How Great Leaders Think: The Art Of Reframing, John Wiley \& Sons Publisher, New Jersey.

BÜYÜKÖZTÜRK, Şener (2014), Sosyal Bilimler İçin Veri Analizi Eı Kitabı: İstatistik, Araştırma Deseni SPSS Uygulamaları ve Yorum, Pegem Akademik Yayınları, Ankara.

BÜYÜKÖZTÜRK, Şener, KILIÇ ÇAKMAK, Ebru, AKGÜN, Özcan Erkan, KARADENIZ, Şirin ve DEMİREL, Funda (2012), Bilimsel Araştırma Yöntemleri, Pegem Akademik Yayınları, Ankara, 11.Bask1.

CANSOY, Ramazan ve TOFUR, Sezen (2017), "Examining The Relationship Between Teacher Candidates' Individual Values and Leadership Orientations", Journal of Education and Practice, S.8(2), ss.101113.

CARRILlO, Rosa Antonia (2019), The Relationship Factor in Safety Leadership: Achieving Success Through Employee Engagement, Routledge Publisher, Abington.

CLARK, Kenneth E. ve CLARK, Miriam B. (1990), “Measures of Leadership”, Conference on Psychological Measures and Leadership, Leadership Library of America.

ÇOKLUK, Ömay, ŞEKERCIOĞLU, Güçlü ve BÜYÜKÖZTÜRK, Şener (2012), Sosyal Bilimler İçin Çok Değişkenli İstatistik: SPSS ve Lisrel Uygulamaları, Pegem Akademi Yayınları, Ankara.

DE VELLISS, Robert F. (2014), Ölçek Geliştirme: Kuram ve Uygulamalar, Nobel Yayıncılık, Ankara.

DERELI, Mahçe (2003), "A Survey Research of Leadership Styles of Elementary School Principles", Unpublished Master Thesis, Middle East Technical University Faculty of Education, Ankara.

DUROCHER, Elizabeth Antoinette (1997), "Leadership Orientations of School Administrators: A Survey of Nationally Recognized School Leaders", Thesis, Columbia University Teachers College.

ELMUTI, Dean, MINNIS, William ve ABEBE, Michael (2005), "Does Education Have a Role in Developing Leadership Skills?", Management Decision, S.43(7/8), ss.1018-1031.

EROL, Eren (2008), Yönetim ve Organizasyon (Çağdaş ve Küresel Yaklaşımlar), Beta Yayınevi, İstanbul.

ERKUŞ, Adnan (2014), Psikolojide Ölçme ve Ölçek Geliştirme-I: Temel Kavramlar ve İşlemler, Pegem Yayınları, Ankara, 2.Bask1.

ESENTÜRK, Oğuz Kaan, YILMAZ, Aynur, İLHAN, Ekrem ve KAN, Adnan (2019), "Beden Eğitimi Öğretmeni Kişilerarası Öz-Yeterlik Ölçeği’nin Psikometrik Özelliklerinin İncelenmesi”, Gazi Beden Eğitimi ve Spor Bilimleri Dergisi, S.24 (2), ss.63-88.

FRAENKEL, Jack R. ve WALLEN, Norman E. (2000), How to Design And Evaluate Research in Education, McGraw Publisher, New York.

HAN, Joo Hun, LIAO, Hui, TAYLOR, M. Susan ve KIM, Seongsu (2018), "Effects of High-Performance Work Systems on Transformational Leadership And Team Performance: Investigating The Moderating Roles of Organizational Orientations", Human Resource Management, S.57(5), ss.1065-1082.

HOOPER, Daire, COUGHLAN, Joseph ve MULLEN, Michael (2008), "Structural Equation Modelling: Guidelines For Determining Model Fit", Electronic Journal of Business Research Methods, S.6(1), ss.53-60.

HORTAÇSU, Nuran (1998), Grup İçi ve Gruplar Arası Süreçler, İmge Kitapevi Yayınları, Ankara.

IGBİNAKHASE, Idahosa ve NAIDOO, Vannie (2019), "Global Leadership Competencies and Orientations: Theory, Practice, And Future Implications”, Contemporary Multicultural Orientations And Practices for Global Leadership, ss.59-79.

KALFA, Murat (2019), "Yönetim ve Spor", Spor Bilimleri Araştırmaları (Ed. Zeynep Filiz Dinç), Akademisyen Kitabevi, Ankara, ss.73-88.

KARASAR, Niyazi (2014), Bilimsel Araştırma Yöntemleri: Kavramlar, Teknikler ve İlkeler, Nobel Yayınevi, Ankara, 27.Bask1.

KILIÇ CAKMAK, Ebru, ÇEBİ, Aynur ve KAN, Adnan (2014), "Developing A Social Presence Scale for E Learning Environments", Kuram ve Uygulamada Eğitim Bilimleri Dergisi, S.14, ss.764-768. 
DURSUN, Mücahit, GÜNAY, Mehmet ve YENEL, Fatih - Çok Yönlü Liderlik Yönelimleri Ölçeği (ÇYLYÖ): Geçerlik ve Güvenirlik Çalışması

KIM, Dongkyou, CHOİ, Dongwon ve VANDENBERGHE, Christian (2018), "Goal-Focused Leadership, Leader-Member Exchange, And Task Performance: The Moderating Effects of Goal Orientations And Emotional Exhaustion", Journal of Business And Psychology, S.33(5), ss.645-660.

KLINE, Patrick (1998), Principles And Practice of Structural Equation Modeling, Routledge Publisher, New York.

MUJTABA, Bahaudin G. (2019), "Leadership Orientation of Afghan and Japanese Respondents: A Study of "Guzaara" or Getting Along in Asia", Information Management And Business Review, S.11(1), ss.2439.

NGUYEN, Lam D, TANNER, Thomas ve PHAM, Loan N. (2019), "Cross-Culture Management: An Empirical Examination on Task And Relationship Orientations of Japanese And Omani Working Adults", International Journal of Human Resources Development and Management, S. 19(1), ss.92103.

NUnNally, Jum C. ve BENSTEIN, Ira (1994), Psychometric Theory, Mc-Graw Hill, New York, 3.Bask1.

ÖZCAN, Kenan ve BALYER, Aydın (2013), “Liderlik Oryantasyon Ölçeğinin Türkçeye Uyarlanması”, Mersin Üniversitesi Eğitim Fakültesi Dergisi, S.9(1), ss.136-150.

ÖZDEMİR, Murat (2018), "Liderlik Yönelimi ve Politik Beceri Arasındaki İlişkinin Okul Müdürlerinin Görüşlerine Göre Incelenmesi”, Ege Eğitim Dergisi, S.19(1), ss.116-134.

ÖZDEMIR, Yalçın, BUYRUK, Halil ve GÜNGÖR, Sabri (2018), “Öğretmen Adaylarının Eleştirel Düşünme Eğilimi ile Liderlik Yönelimleri Arasındaki İlişki”, Mersin Üniversitesi Eğitim Fakültesi Dergisi, S.14(2), ss.548-571.

PEERS, Lan (1996), Statistical Analysis For Education and Psychology Researchers: Tools For Researchers In Education And Psychology, Falmer Press, London.

SCHERMELLEH ENGEL, Karin, MOOSBRUGGER, Helfried ve MÜLLER, Hans (2003), "Evaluating The Fit of Structural Equation Models: Tests of Significance And Descriptive Goodness-of-Fit Measures", Methods of Psychological Research Online, S.8(2), ss.23-74.

SEÇER, İsmail (2013), SPSS ve Lisrel İle Pratik Veri Analizi: Analiz ve Raporlaştırma, Anı Yayıncılık, Ankara.

ŞEKER, Hasan, DENIZ, Sabahattin ve GÖRGEN, İsmail (2004), “Öğretmen Yeterlikleri Ölçeği”, Milli Eğitim Dergisi, S.164, ss.105-118.

ŞENCAN, Hüner (2005), Sosyal ve Davranışsal Ölçümlerde Güvenilirlik ve Geçerlilik, Seçkin Yayınları, Ankara.

ŞİMŞEK, Emel ve GARIPAĞAOĞLU, Burçak Çağla (2016), “Bolman ve Deal’in Dört Çerçeve Modeline Göre Akademik Liderlerin Liderlik Yaklaşımlarının Incelenmesi”, İnönü Üniversitesi Eğitim Fakültesi Dergisi, S.17(1), ss.81-94.

TABACHNICK, Barbara G. ve FIDELL, Linda S. (2007), Using Multivariate Statistics, Allyn And Bacon Publisher, Boston, 5.Bask1.

TAVŞANCIL, Ezel (2014), Tutumların Ölçülmesi ve SPSS Veri Analizi, Nobel Yayınları, Ankara.

TEKİN, Halil (2004), Eğitimde Ölçme ve Değerlendirme, Yargı Yayınevi, Ankara, 17. Bask1.

TEZBAŞARAN, Ata (2008), Likert Tipi Ölçek Geliştirme Kılavuzu, Türk Psikologları Derneği Yayınları, Ankara, 3. Bask1.

THOMPSON, Michael D. (2005), "Organizational Climate Perception and Job Element Satisfaction: A MultiframeApplication in a Higher Education Setting". E-Journal of Organizational Learning And Leadership, S.4, ss.1-16.

YENEL, İbrahim Fatih (2018), "Liderlik", Yönetim ve Spor (Ed. Ahmet Azmi Yetim), Gazi Kitabevi Yayınları, Ankara, ss.293-312.

YILDIRIM, Ali ve ŞİMŞEK, Halil (2011), Sosyal Bilimlerde Nitel Araştırma Yöntemleri, Seçkin Yayınları, Ankara. 


\section{Ek: Çok Yönlü Liderlik Yönelimleri Ölçeği (ÇYLYÖ)}

\begin{tabular}{|c|c|c|c|c|c|}
\hline Çok Yönlü Liderlik Yönelimleri & 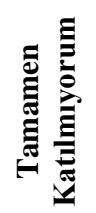 & 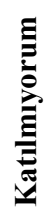 & 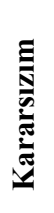 & 㤩 & 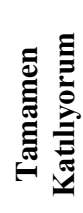 \\
\hline 1. Mantıklı düşünürüm. & & & & & \\
\hline 2. Başkalarının sorunlarına karşı duyarlı & & & & & \\
\hline 3. İnsanları harekete geçirme yeteneğine & & & & & \\
\hline 4. Dikkatli plan yaparım. & & & & & \\
\hline 5. Planlanan işlerin zamanında bitirilme & & & & & \\
\hline 6. İnsanları ikna etmede başarılıyım. & & & & & \\
\hline 7. Problemleri mantıklı düşünerek çözer & & & & & \\
\hline 8. Başkasının fikirlerini önemserim. & & & & & \\
\hline 9. Güç sahibi insanların desteğini almad & & & & & \\
\hline 10. İnsanları etkileme yeteneğine sahibim & & & & & \\
\hline 11. İnsanlar için ilham kaynağıyım. & & & & & \\
\hline 12. İnsanlar arasındaki sorunları çözme $\mathrm{k}$ & & & & & \\
\hline 13. Yaratıcı bir insanımdır. & & & & & \\
\hline 14. İnsanlara yardım etmeyi severim. & & & & & \\
\hline 15. Kendimi karizmatik bulurum. & & & & & \\
\hline 16. Heyecan verici yeni fikirler yaratırım & & & & & \\
\hline 17. İyi bir dinleyiciyim. & & & & & \\
\hline 18. Zorluklara rağmen başarıya ulaşırım. & & & & & \\
\hline 19. Doğru kararlar vermede başarılıyım. & & & & & \\
\hline
\end{tabular}

